DOI 10.33463/2712-7737.2019.01(1-3).1.059-064

Ponomarev S. B., Lehmann Marc

Пономарев С. Б., Лехманн Марк

\title{
THE OUTCOME OF RUSSIA'S MEMBERSHIP \\ IN THE NORTHERN DIMENSION PARTNERSHIP PRISON HEALTH EXPERT GROUP
}

\section{РЕЗУАЬТАТЫ УЧАСТИЯ РОССИИ \\ В РАБОТЕ ЭКСПЕРТНОЙ ГРУППЫ \\ ПО ТЮРЕМНОМУ ЗАРАВООХРАНЕНИЮ \\ ПАРТНЕРСТВА «СЕВЕРНОЕ ИЗМЕРЕНИЕ»}

\begin{abstract}
The International partnership «Northern Dimension» includes states located in the northern region of the earth planet: Finland, Sweden, Norway, Iceland, Russia, Denmark, Germany, Poland and the Baltic countries. The work of the partnership «Northern Dimension (ND)» covers a wide range of areas: education, culture, nuclear and environmental safety, the development of gas condensate and oil fields, health, transport, energy, science, etc. In particular, joint projects relate to the cooperation between the Northern Dimension countries in the Arctic, in the Baltic and Barents Seas, in developing of Northern Sea commercial use, the Baltic oil pipeline creation and other projects. Under the umbrella of the partnership of health and social wellbeing an independent group of experts of prison health is working since 2015.The work of this EG is headed by the elected national representative of Germany and his deputy the national representative of Latvia. The main goal of the prison health expert group work is to reduce the spread of typical diseases in prison (HIVIAIDS, tuberculosis, sexually transmitted infections, cardiovascular diseases, malignoma et cetera). In 2016-2018 five meetings of the group were performed (Berlin - two meetings, Riga, Moscow, Warsaw), in four of which Russian representative made reports about the Russian prison medical care status. In these reports it has been shown that the penitentiary medicine of the Russian Federation steadily and methodically demonstrates positive changes that are reflected in the dynamics of the main intensive and extensive indicators. There is notable positive outcome of the group meetings with Russian membership. Representatives of the north European countries prison systems have received firsthand reliable information about the Russian penitentiary healthcare system status. In high level expert discussions the presented data are evaluated and responced suggested. This will undoubtedly contribute to the process of further improvement of international relations with benefits for Russian system.
\end{abstract}

(C) Ponomarev S. B., Lehmann Marc, 2019

(C) Пономарев С. Б., Лехманн Марк, 2019 
Key words: international partnership, «Northern Dimension», group of experts, prison health, penal system.

Аннотация. Международное партнерство «Северное измерение» включает в себя страны, расположенные в Северном полушарии планеты Земля: Финляндию, Швецию, Норвегию, Россию, Исландию, Данию, Германию, Польшу и государства Прибалтики. Деятельность «Северного измерения» охватывает широкий круг вопросов: образование, культуру, экологическую и ядерную безопасность, разработку газовых и нефртяных месторождений, здравоохранение, транспорт, энергетику, науку и т. д. Совместные проекты касаются взаимодействия стран «Северного измерения» в Арктике, Баренцевом и Балтийском морях, коммерческом использовании Северного морского пути, проектирования Балтийской нефтепроводной системы и пр. В составе партнерства в области общественного здравоохранения и социального благополучия с 2015 г. работает независимая экспертная группа по пенитенциарному здравоохранению. Работой группы руководит представитель Германии, его заместителем является представитель Латвии. Главная цель работы экспертной группы по пенитенциарному здравоохранению - сокращение уровня заболеваний, присущих местам лишения свободы (ВИЧ-СПИД, туберкулез, инфекции, передающиеся половым путем, сердечно-сосудистые, онкологические заболевания и т. д.). В 2016-2018 гг. состоялось 5 встреч группы экспертов, на которых представитель Российской Федерации выступил с докладами о состоянии пенитенциарной медицины в России. В этих докладах было показано, что в России система медицинского обеспечения в местах лишения свободы неуклонно и методично демонстрирует позитивные сдвиги, которые находят отражение в динамике основных интенсивных и экстенсивных показателей. Следует отметить положительный итог состоявшихся совещаний с участием представителя Российской Федерации. Представители тюремных систем стран Северной Европы получили достоверные сведения о положении дел в российской пенитенциарной медицине. В ходе обсуждения представленные данные были высоко оценены международными экспертами. Это, несомненно, будет способствовать процессу дальнейшего улучшения международных отношений с пользой для российской пенитенциарной системы.

Ключевые слова: международное сотрудничество, «Северное измерение», группа экспертов, тюремное здравоохранение, пенитенциарная система.

\section{Information about authors / Сведения об авторах}

Sergej Borisovich Ponomarev, MD, professor, chief researcher, Research Institute of the FPS of Russia, Moscow, Russian Federation, ORCID 0000-0002-9936-0107, ResearcherID 1-2905-2018, e-mail: filialniifsin@mail.ru.

Сергей Борисович Пономарев, доктор медицинских наук, профессор, главный научный сотрудник, Научно-исследовательский институт ФСИН России, г. Москва, Российская Федерация, ORCID 0000-0002-9936-0107, ResearcherID 1-2905-2018, e-mail: filialniifsin@mail.ru.

Marc Lehmann, Medical advisor Prison Health, Chair of Prison Health Expert Group Northern Dimension Partnership in Public Health and Social Well-being, Berlin, Federal Republic of Germany, e-mail: marc.lehmann@jvapls.berlin.de. 
International penitentiary journal, 2019, vol. 1(1-3), iss. 1

Марк Лехманн, медицинский советник по охране здоровья заключенных, председатель экспертной группы по пенитенциарному здравоохранению Международного партнерства «Северное измерение», г. Берлин, Федеративная Республика Германия, e-mail: marc.lehmann@jvapls.berlin.de.

\section{Recommended citation / Для цитирования}

Ponomarev, S. B. \& Lehmann, Marc 2019, 'The outcome of Russia's membership in the Northern Dimension Partnership Prison Health Expert Group', International penitentiary journal, vol. 1(1-3), iss. 3, pp. 59-64, doi: 10.33463/2712-7737.2019.01(1-3).1.059-064.

Пономарев, С. Б. Результаты участия России в работе экспертной группы по тюремному здравоохранению Партнерства «Северное измерение» / С. Б. Пономарев, Марк Лехманн // Международный пенитенциарный журнал. - 2019. - Т. 1(1-3), № 1. C. 59-64. - DOI : 10.33463/2712-7737.2019.1(1-3).01.059-064. 
The international partnership "Northern Dimension" includes states located in the northern region of the earth planet: Finland, Sweden, Norway, Iceland, Russia, Denmark, Germany, Poland and the Baltic countries. The United States and Canada are observers in the "Northern Dimension". The Republic of Belarus participates in some projects of the partnership. The aim of the Northern Dimension is the prosperity support and sustainable development in northern Europe countries by practical cooperation.

The work of the partnership "Northern Dimension" (ND) covers a wide range of areas: education, culture, nuclear and environmental safety, the development of gas condensate and oil fields, health, transport, energy, science, etc. In particular, joint projects relate to the cooperation between the Northern Dimension countries in the Arctic, in the Baltic and Barents Seas, in developing of Northern Sea commercial use, the Baltic oil pipeline creation and other projects. The activities of the ND are covered by financial structures, e. g. the Northern Investment Bank, the European Bank for Reconstruction and Development, the Nordic Environmental Finance Corporation, and the European Investment Bank.

The international cooperation ND includes four main bodies: the environmental partnership, the partnership in transport and logistics, the partnership in the field of culture and a partnership in public health and social well-being NDPHS. Their mission is to promote the sustainable development of the northern European countries by improving the health of citizens and increasing the level of social welfare. These can be achived by improving the political and administrative cooperation between countries, reducing socio-economic imbalances and improving the life quality of the people of the northern region.

Under the umbrella of the partnership of health and social wellbeing NDPHS, an independent group of experts of prison health is working since 2015.The work of this EG is headed by the elected national representative of Germany and his deputy the national representative of Latvia.

The purpose of the article is to analyze activities of Russia in the prison health group of the Northern Dimension Partnership.

The work of the prison health expert group is based on the implementation of a strategy that closely interconnects the medical prison structures of participating countries.

The main goal of the prison health expert group (EGPH) work is to reduce the spread of typical diseases in prison (HIVIAIDS, tuberculosis, sexually transmitted infections, cardiovascular diseases, malignoma et cetera). Another significant goal is to increase the level of social welfare of people released from imprisonment, to promote their socially useful way of life (Lehmann, M. 2016, p. 8-12). To achive best results prison health experts work in close collaboration to other NDPHS Expert Groups like HIV Group, substance misuse Group and others.

According to these goals, the EGPH tasks are:

1. Improving the interaction between national health care systems and penitentiary systems.

2. Development of integration between the partner countries of the Northern Dimension on issues related to prison medicine by the exchange of experience and necessary resources.

3. Minimization of the negative penal factors common to partner countries, such as the overpopulation of prisons, which is the serious risk of the infectious diseases spreading.

4. Reducing disparities in the level of medical care, and approaching compliance with the principle of medical care equivalence between the penitentiary system and civil health care system. Applying the standards of treatment (part of the national health systems standards) in the penal system.

5. Control the quality of work and the level of professional skills, training and education of medical staff in the prison system.

6. Strengthening of ethical and public responses to HIVIAIDS, tuberculosis and other 
infectious diseases characteristic of the penal system.

7. Ensure the access of all HIV-infected prisoners in the Northern Dimension partner countries to antiretroviral therapy and other necessary treatment methods according to the national recommendations.

8. Promotion of all necessary measures to reduce the cases of tuberculosis in the penitentiary system.

9. Ensure prisoners' access to the same drug treatment and counseling programs that are available to the general population.

10. Strengthening the treatment of people with mental diseases in the prison systems of the countries participating in the "Northern Dimension" partnership.

11. Developing policies, practices and programs for women in prisons. Particular attention is paid to the joint living of mothers and small children, as well as adolescent girls.

12. Monitoring the vocational training to provide the integration into society after prisoners release from places of deprivation of liberty.

13. Ensuring the development of social connections between prisoners and their families.

14. Ensuring the adherence of prisoners to a healthy lifestyle, the refusal of smoking and alcohol, monitoring the nutrition of prisoners, providing physical education, improving mental health.

15. Solving the problem of treatment after the sick prisoners release from places of deprivation of liberty.

Notably that these areas of work of a group of prison health international experts are based on the principles outlined in the Northern Dimension Partnership Development Strategy until 2020. In the field of prisoner's health this strategy includes reducing of the HIV infection, tuberculosis and other infectious diseases spread among prisoners, by preventive and curative efforts, which includes exchanging the experience of the participating countries in the organization of prevention, treatment, health education, counseling and monitoring. It is notorious that prisoners all over the world are socially marginalized contingents with an increased risk for HIV infection, tuberculosis, sexually transmitted diseases, drug pathology, and mental diseases, which makes medical issues in prisons especially relevant.

In 2016-2018 five meetings of a PHEG group were performed (Berlin - two meetings, Riga, Moscow, Warsaw), in four of which Russian representative made reports about the Russian prison medical care status. In these reports it has been shown that the penitentiary medicine of the Russian Federation steadily and methodically demonstrates positive changes that are reflected in the dynamics of the main intensive and extensive indicators. The indicators characterize some aspects of the medical service: morbidity, mortality, prevalence of diseases (Abramova, M. A., Romanov, K. A. \& Ponomarev, S. B. 2012, pp. 342-345; Djuzheva, E. V. \& Ponomarev, S. B. 2016, p. 32-37). The positive changes in departmental medicine and in the penal system in general have been demonstrated. The work of all expert groups is documented in protocols which are available on the NDPHS Website in Chapter Meetings: www.ndphs.org.

For example, it was reported that the number of prisoners in Russia has been decreasing year by year - from more than one million people in 1999 to 602,200 in 2018. The senumbers reflected the positive changes that are taking place in the life of society: the stabilization of the economic situation, the intensification of the struggle against crime and crime prevention. Especially the number of juvenile convicts has significantly decreased (10 times compared to 2005) (Ponomarev, S. B., Pustovalov, A. R. \& Burt, A. A. 2016, p. 118-119). The number of female prisoners is also decreasing. This is due to the humanization of the penal system and the decriminalization in Russian legislation.

For the Russian penitentiary system, the challenges caused by tuberculosis, HIV infection, viral hepatitis, alcoholism and drug addiction, as well as cardiovascular and mental diseases remain relevant. The Department of Prison Health Service is constantly taking measures monitoring combating these dis- 
eases (Abramova, M. A., Romanov, K. A. \& Ponomarev, S. B. 2012, p. 342-343). Especially notable is the positive development of the indicators for tuberculosis (Ponomarev, S. B. 2016, p. 87-89). The constant reducing tendency of newly detected tuberculosis cases in the penal system is registered. And the number of deaths caused by tuberculosis decreased by 10 times in the last 8 years.

At the same time, the negative trends in Russian society, such as the spread of drug addiction, prostitution and the reality of homosexuality increase the spread of HIV in the general population. This results in increase of number of HIV positive prisoners. The incidence of co-infection of tuberculosis + HIV has increased dramatically. The majority of HIV-carriers in places of deprivation of liberty are inmates, whose infections was first diagnosed by prison doctors. Beside this we have to accept that HIV infection often goes hand in hand with drug addiction and viral hepatitis. It was shown that HIV-positive convicts become the best access to preventive care and treatment including highly active antiretroviral therapy.

International experts of "Northern Dimension" partnership has been informed that the increase of the number of patients with HIV infection and viral hepatitis in Russia's prison system is primarily caused by the intensification of criminal gangs engaged in drug trafficking. Identification of these patients in the penal system is necessary and the situation can be improved by the strengthening of the fight against organized crime and by improving the social and economic situation in Russia. The convicts mortality data were also reported. It was presented that the dynamics of mortality in the penitentiary system follows a significant downward trend.

EG was also informed that one of the reasons for the reported incidence of HIV infections, viral hepatitis, tuberculosis among the prison population is the high rate of diagnostic examinations. A rate of nearly $100 \%$ of persons admitted to the institutions of the correctional system is a big success and currently not achieved in the "civilian" population. The lower rate in the outside community might be caused by the limited adherence to the medical system of persons without lack of registered place of residence. It was emphasized that in Russian Prisons a process has been implemented to improve the medical and social care to mothers-prisoners and their children who are living in prisons children's homes.

In conclusion, there is notable positive outcome of the PHEG meetings with Russian membership. Representatives of the north European countries prison systems have received firsthand reliable information about the Russian penitentiary healthcare system status. In high level expert discussions the presented data are evaluated and responced suggested. This will undoubtedly contribute to the process of further improvement of international relations with benefits for Russian system.

\section{References}

Lehmann, M. 2016, 'Northern Dimension Partnership for Public Health and Social Well-Being (NDPHS)', Penitentiary medicine in Russia and abroad: Proceedings of the International interdepartmental conference, Moscow, pp. 8-12.

Abramova, M. A., Romanov, K. A. \& Ponomarev, S. B. 2012, 'Organizational aspects of providing the medical aid for convicted. Third forum of young researchers', Educational Quality, pp. 342-345.

Djuzheva, E. V. \& Ponomarev, S. B. 2016, 'Analysis of mortality from noncommunicable diseases among persons contained penal system', International research journal, no. 9(40). part 4, pp. 35-37.

Ponomarev, S. B., Pustovalov, A. R. \& Burt, A. A. 2016, 'Theoretical aspects of penal juvenology', International research journal, no. 6(48), pp. 118-119.

Ponomarev, S. B. 2016, 'Russia's membership in the international project "Northern dimension" in the provision of health care to prisoners', Eastern european scientific journal, no. 4 , pp. 87-89. 